\title{
ENABLING INDIGENOUS URBAN DESIGN: \\ AN EXAMINATION OF THEORY AND PRECEDENTS \\ FOR APPLICATION IN WINNIPEG
}

\author{
By: \\ Neil Loewen \\ B.Env.D., University of Manitoba, 2013 \\ A Major Research Paper \\ presented to Ryerson University \\ in partial fulfillment of the requirements for the degree of \\ Master of Planning \\ in \\ Urban Development
}

Toronto, Ontario, Canada, 2016

(C) Neil Loewen 2016 


\section{AUTHOR'S DECLARATION FOR ELECTRONIC SUBMISSION OF A MRP}

I hereby declare that I am the sole author of this MRP. This is a true copy of the MRP, including any required final revisions.

I authorize Ryerson University to lend this MRP to other institutions or individuals for the purpose of scholarly research

I further authorize Ryerson University to reproduce this MRP by photocopying or by other means, in total or in part, at the request of other institutions or individuals for the purpose of scholarly research.

I understand that my MRP may be made electronically available to the public. 


\title{
Enabling Indigenous Urban Design: A Review of Theory and Precedents for Application in Winnipeg
}

(C) Neil Loewen 2016

Master of Planning

in

Urban Development

Ryerson University

\begin{abstract}
This research paper explores strategies for including Indigenous identities in the design of urban spaces and provides recommendations for the City of Winnipeg. As Canada's Indigenous population is now primarily situated in urban areas there is growing demand for First Nations, Métis, and Inuit cultural expression to influence the design of the spaces these populations inhabit in cities. A review of salient literature pertaining to Indigenous involvement in planning processes and the translation of culture into urban design provides a theoretical basis for further investigation. Auckland, Aotearoa New Zealand's Maori Design Principles are used as a relevant precedent study. The search for precedents uncovers that practice is lagging far behind theory. Theory and precedent study inform a series of recommended actions for the City of Winnipeg with the intent of enabling Indigenous urban design in both reserve and off-reserve settings.
\end{abstract}

Key words: Indigenous; urban design; Winnipeg; design policy. 


\section{Acknowledgements}

Thank you to Ron Keeble for supervising me through this endeavour, and always giving me the boost of confidence I needed.

Thank you to my parents, for unwavering support as I moved from the farm, to the city, and across the country; for pretending to be as interested in planning as me, and listening to my urban design audiobooks on one long, long road trip. Thank you for everything.

Thank you to my classmates, who have become the closest of friends. The friendships we've formed over the last two years matter more to me than the degree I moved here for. While we may be about to embark on new adventures near and far, l'll keep these memories with me forever. Thank you. 


\section{Table of Contents}

Abstract......................................................................

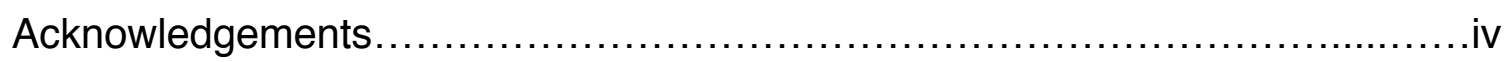

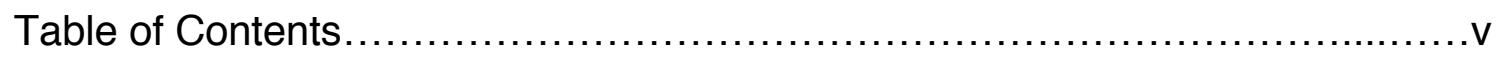

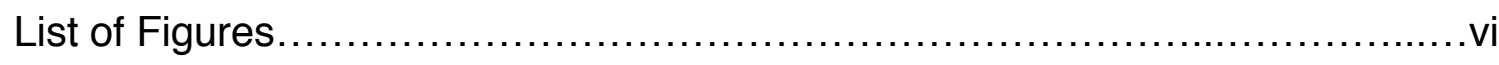

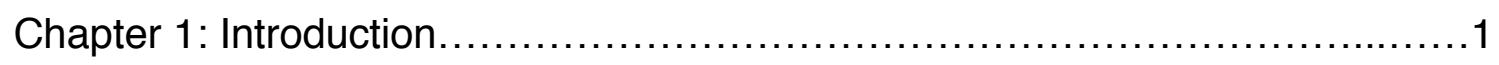

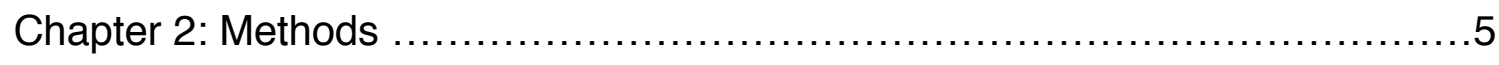

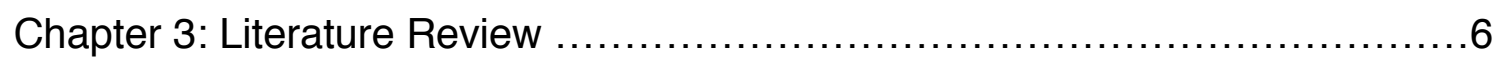

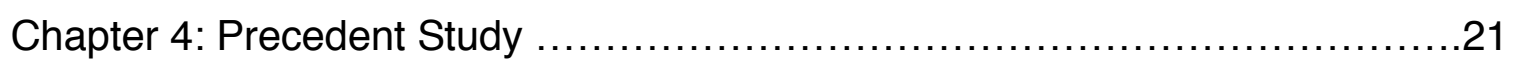

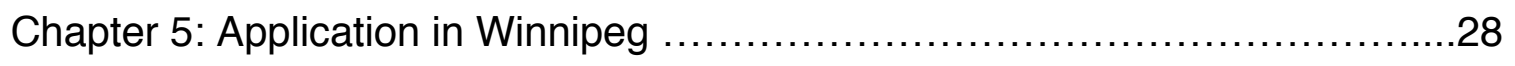

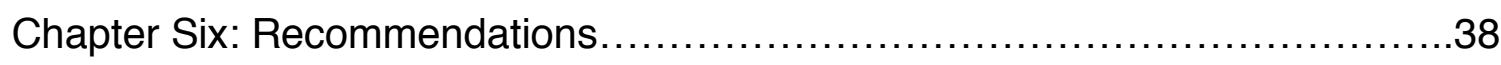

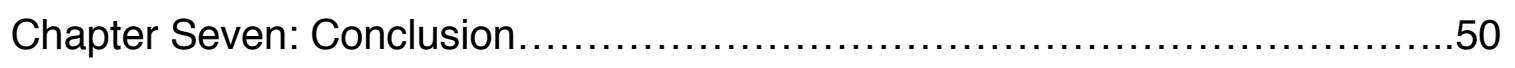

References.......................................................... 51 


\section{List of Figures}

Figure 1: Urban Indigenous Population in Canada Over Time.....................2

Figure 2: Policy documents leading to the Auckland Design Manual and Maori

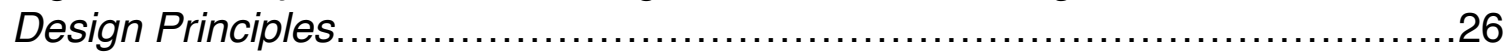

Figure 3: Frequency of key words relating to Indigenous people in OurWinnipeg.

Figure 4: Frequency of key words relating to Indigenous people in Winnipeg's Complete Communities Direction Strategy .....................................34

Figure 5: Frequency of key words relating to Indigenous people in the Downtown Winnipeg Urban Design Guidelines..............................................36 


\section{Chapter One: Introduction}

The twenty-first century has brought increased urbanization of Canada's rapidlygrowing Indigenous population. By 2011, Indigenous people living in urban areas represented $56 \%$ of the Canada's Indigenous population (Statistics Canada, 2013). This is up from $49 \%$ in 1996 . This means that for the first time in Canadian history, over half of the Indigenous population lives in cities. The largest concentrations of urban Indigenous people were in Winnipeg $(78,420)$, Edmonton $(61,765)$, Vancouver $(52,375)$, and Toronto $(36,995)$. (Indigenous and Northern Affairs Canada, 2014). On the whole, Canada's Indigenous people make up $3.8 \%$ of the total population a proportion that is now second only to Aotearoa New Zealand's, where $14 \%$ of the population is Maori (Statistics New Zealand, 2006).

"Most aboriginal people living in cities (71 per cent) consider their city "home," not simply a transitional place to get a job or go to school. And two-thirds (65 per cent) say they like living in the city "a lot."'” - Urban Aboriginal Peoples Study (Environics Institute, 2011).

Canada's urban Indigenous population is not unrooted and transient. Indigenous Canadians living in cities overwhelmingly consider their city to be home, contrary to the perception by many Canadians that Indigenous communities consider the reserve to be home (despite the many Canadian's assumption that Indigenous people consider their home to be the reserve (Adams \& Gosnell-Myers, 2013).

"The city's culture can be used to express the individual identities, character and uniqueness of its people and is able to contribute to the development of a sense of place." (Wannsborough and Mageean. 2000. Pp. 187) 


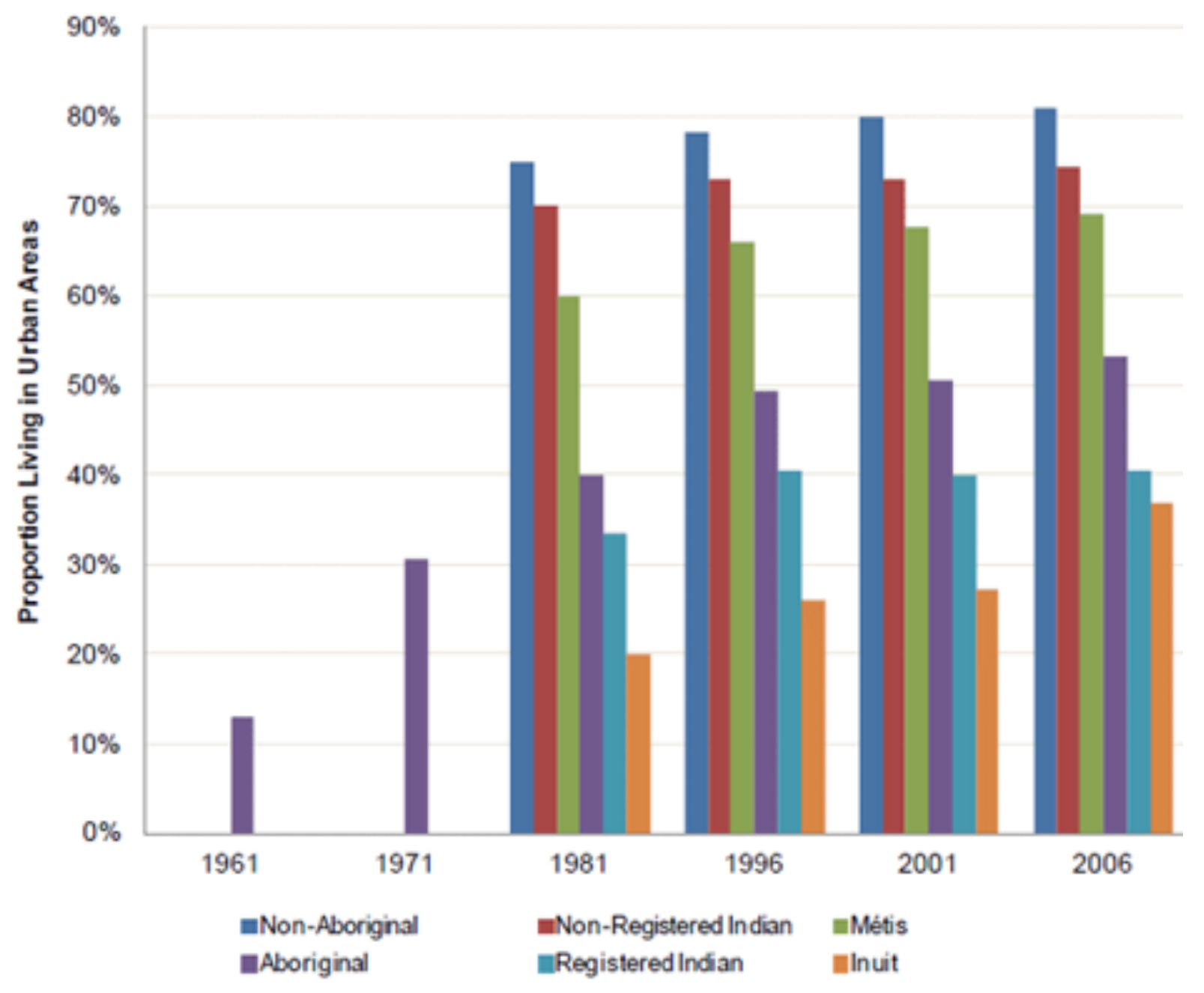

Figure 1: Urban Indigenous Population in Canada Over Time. (Indigenous and Northern Affairs Canada, 2014)

\section{A Colonial Planning Tradition}

Despite the increasing urbanization of Canada's Indigenous population, and the overall ethnic diversity present in all major Canadian cities in the 21st century, the planning process has remained largely unchanged over the past 30 years. The small adaptations that have been made include expanded emphasis on consultation of affected publics, and ensuring that policies promoting 
multiculturalism in this period are adhered to (Qadeer, 1997). However, the format that these adaptations occur within remains largely of a Western tradition (Belanger and Walker, 2013). While neutrality may have been the goal for some time, it is now understood that the practice of urban planning is not and cannot ever be value-neutral (Andersen, 2013). With this recognition, planners and designers must understand the values that are brought to the work they carry out and attempt to ensure that the values of those affected are being represented.

The impact of an inelastic planning process is that Winnipeg's 26,000 First Nations residents (Statistics Canada, 2013) live in homes, inhabit neighbourhoods, and visit public spaces that are physical manifestations of settler culture and the imposition of foreign values. Both built forms that predate the rise of urban Indigenous populations and more recent developments have been delivered through a process that has not adjusted to reflect the identities of those it serves. This may reduce the potential for cultural regeneration, and lead to increasing alienation of inhabitant populations from the city as a whole (Wannsborough, Mageean. 2000. Pp. 185).

\section{The Role of Planner in Indigenous Urban Design}

In addition, urban design regulations are a function of municipal governments and thus the resulting built form is an expression of the goals of the municipal government. While much urban design occurs on private property, the control and guidance of these forms is public. As Dorries (2012, Pp. 99) has argued, 
"public goals are made legible on private property". If Canadian multiculturalism, and further the federal recognition of Indigenous rights and sovereignty are to be adhered to, urban design becomes an important intersection point. To understand how Indigenous identities can be manifested in urban design, we must understand the planning process that governs the design of urban spaces in Canadian cities.

Research Questions:

1. How can the values, cultures, and identities of Indigenous groups find physical form in urban areas?

2. What can the City of Winnipeg do to enable greater inclusion of Indigenous identities in urban design?

Objectives:

1. Gain an understanding of how urban planning processes can better include Indigenous communities

2. Explore best practices in the contemporary expression of Indigenous architecture and design

3. Examine processes of Indigenous inclusion in urban design from around the world

4. Determine applicable recommendations for the City of Winnipeg 


\section{Chapter Two: Methods}

This paper involves secondary research using comparative case studies and precedents to inform analysis of planning processes in Winnipeg. A literature review was conducted to explore theoretical discussion of Indigenous identities in urban space, urban design processes, multiculturalism in Canadian cities, and related developments in Winnipeg and Canada. A precedent study was conducted to compare relevant cases to Winnipeg for an understanding of best practices in Indigenous urban design. The review of suitable precedents uncovered that very few cities around the world have made progress on the subject, with the only comparable city to Winnipeg that can be used as a precedent study being Auckland, Aotearoa, New Zealand. The outcomes and history in Auckland are related to Winnipeg's. Secondary precedents were also studied, including smaller projects and non-municipal initiators. Finally the common threads of the literature review, as well as findings from the precedent study were compiled and analyzed to create a series of recommendations for the City of Winnipeg, Planning, Property, and Development department. The review of case studies is a method common to both policy recommendation works and indigenous cultural research. A similar approach was taken by Awetere et al (2010) to draw together a series of Maori design principles. Planning literature and practice in Canada lack sufficient representation of Indigenous voices, and the research scope had to include other English settler-states. There is a need for more First Nations-centred urban planning research in order to inform similar studies and urban planning practice in years to come. 


\section{Chapter Three: Literature Review}

Research into Indigenous design has previously been largely focused on developing the spaces on First Nations reserves in rural areas to reflect tenets of the local culture and architectural history (Peters \& Walker. 2005. pp.330). For the purposes of this paper, it is important to understand three other geo-political environments for which the inspection of Indigenous community design can be undertaken. In addition to rural first nations reserves, there are Indigenous communities living off-reserve in rural areas, on-reserve in urban areas, and offreserve in urban areas. The process of addressing Indigenous community design will be distinct in each of these environments.

It must be noted that two distinct trajectories appear to exist in Indigenous planning literature between rural and urban Indigenous planning. Environmental planning discourse, touching on rural areas within British settler-states, has accepted a necessary coexistence of Indigenous and western values. This has allowed relationships between Indigenous groups, governments, and private companies involved in the natural resource industry to progress to a more mutually beneficial state than had previously been possible. However, this same acceptance of multiple coexisting value systems is much less common in urban planning literature (Porter. 2013). 
This research will include policy solutions aimed at engendering Indigenous identities in the designed environments of urban spaces. While it draws on existing rural Indigenous planning discourse, it will not address this issue with respect to rural reserve and non-reserve communities.

\section{Urban Reserves}

While Canada's Indigenous population forms into growing communities in every major city across the country, concurrent land claims have the potential to stake out space under First Nations control within these cities. The Canadian Constitution of 1982 enshrined Indigenous rights and title as legitimate and led to Supreme Court rulings stating the federal government must compensate First Nations communities for land that they are owed since the signing of the treaties. It is recognized that the federal government has a legal "duty to consult" with First Nations communities when there is any indication that a group may have a claim to a piece of public land that is up for sale. Though there is still debate over what constitutes the government fulfilling their "duty to consult", it is expected that this includes some form of accommodation. As a result, land claims on federal surplus land have become increasingly common. Many of these claims are in urban areas where potential economic development opportunities are much higher.

There are a growing number of instances where urban lands have been granted reserve status - providing remote First Nations reserves with a footing in more 
central urban areas. Since the establishment of the first modern urban reserve (excluding reserves that urban areas had grown to encompass) in Saskatoon in 1988 they have sprung up in over 120 instances (Indigenous Corporate Training Inc., 2015).

While the majority of urban Indigenous populations are likely to inhabit nonreserve areas of Canada's cities, urban reserve establishment provides the greatest opportunity for targeted policy that responds directly to the proprietary First Nations community, or communities. Indeed, acknowledgement of Indigenous rights by urban planners and policy makers remain confined to reserve rights, such as the Ontario Planning Act's (1990) stipulation that First Nations bands must be notified for planning projects occurring within $1 \mathrm{~km}$ of their reserve territory (Dorries, 2012. Pp. 62).

Some of the characteristics that enable urban reserves to enshrine Indigenous identities into urban design policy more accurately include a defined geographic area, an ownership structure that more clearly identifies the Indigenous communities to be represented, and the special policy-creating powers that these areas are granted by the federal government.

\section{Defined Geographic Area}

The strict delineation between First Nations territory and the rest of the city preempts any discussion of where it is appropriate or necessary to promote 
Indigenous identities in urban design. Urban reserves have distinct laws within their boundaries, while the rest of the city does not have the same ability to target legislation.

\section{Specific Indigenous Groups}

One of the greatest differences when comparing urban Indigenous communities and rural reserve environments is the mixing of many different Indigenous groups into one community in the city (Peters \& Walker. 2005. pp. 330). Urban reserves provide clarity in this regard as they demarcate territory and ownership to specific or shared First Nations.

\section{Special Policy-creating Powers}

Due to their federally associated nature, reserve lands in general do not have the same legislative restrictions that municipalities have. These added powers provide First Nations communities in cities with flexibility in making land use decisions based on their cultural traits that are not present in the wider city. This is important as the accommodation required to adequately incorporate Indigenous perspectives into the design of urban spaces may go beyond what is possible within the current Western tradition of planning. Porter (2013) articulates the notion that Indigenous perspectives may question even the most basic Western conceptions of "space, place, ownership, human-environment relationships, and governance". Urban reserve creation may offer an opportunity for First Nations communities to follow a land-use and urban design process that 
is oriented to concepts such as property and private ownership. Once a deal is signed between the host municipality and First Nation, the urban reserve has an opportunity to divest itself of the colonial process of land development.

\section{New Communities}

While a premise of the argument for an Indigenous urban design is that urban Indigenous communities are stable, long-term communities that eschew the persistent stereotype of a transient, untethered population, it should be noted that in general urban reserve creation involves development where there was no preexisting Indigenous community. Urban reserves may eventually develop into stable, long-term Indigenous communities, but they also may not feature residential populations at all. Ultimately, in the case of an urban reserve the decision to explore Indigenous urban design possibilities lies with the proprietary First Nation.

\section{Kapyong Barracks, Winnipeg}

A potential development of note is a large land claim on a site in Winnipeg. The site - referred to as "Kapyong Barracks" - is a former military base in Tuxedo, Winnipeg - one of the wealthiest neighbourhoods in Western Canada. The barracks lie along Kenaston Boulevard, a major North - South thoroughfare with high-value commercial districts on either end. Long before the barracks were decommissioned in 2004, several First Nations expressed interest in acquiring the land and creating an urban reserve, but they were ignored. After an ensuing 
decade-long legal battle, it has been determined that the federal government had a duty-to-consult that it failed to meet. Consultations are now underway and resolution - which may include the designation of the lands as an urban reserve may come within the near future (Welch, 2015).

The Kapyong Barracks site represents one of the highest profile First Nations land claims in the country, on a site with potentially huge development opportunity. The type of development and the impacts that it has on both the stakeholder First Nations and City of Winnipeg will be studied as a precedent for similar developments across the country.

\section{Beyond the Urban Reserve}

Urban First Nations reserve creation provides a number of economic development opportunities for otherwise remote First Nations communities, and may create space for targeted services aimed at increasing Indigenous participation in the economy. However, it is unlikely that urban First Nation reserves will ever support a majority of Indigenous residents in most Canadian cities. Canada's burgeoning Indigenous population is moving to urban neighbourhoods across the country. Despite this, the derivation of the spaces they will inhabit in urban life still follows a process skewed heavily to a Eurocentric perspective. There is a need to include Indigenous culture and values in the design of our cities and it goes beyond urban first nation reserves. As Porter (2013)) notes that there is a perception that Indigeneity ought to be celebrated on 
First Nations reserves, but legitimacy of this identity and the right to spaces reflective of it is much less assured in non-reserve urban communities. Indeed, there has been observed in multiple works the preconception that to be "urban" and "Aboriginal" is an "impossible contradiction" (Peters. 1996). Municipalities across Canada must attempt to change the way that they plan spaces so as to decolonize and open it up to a broader segment of the urban population.

\section{Multiculturalism's Planning Imperatives}

The continued diversification of the Canadian population over past decades has been accompanied by necessary accommodations in the sector of urban planning. Discussing the impact of multiculturalism, Peters \& Walker (2005) point to Qadeer's (1997) assessment of changes in the planning profession, including how "race and culture have become significant analytical categories for assessing public needs and analyzing social conditions", how planners must now listen and apply lessons from consultation in new ways (especially when working with minority communities), and how " the scope and procedures of citizen involvement in the planning process have to be modified to accommodate multicultural policies." Finally, he concluded that more work must be done to ensure a greater diversity of representation on decision-making bodies. This has lagged behind the increased diversity of those consulted in planning processes (Qadeer, 1997). 


\section{Urban Design Processes}

The urban design process has been transformed over the last few decades from one relying on a master planner to one relying on a master facilitator who will shepherd affected communities through a generative process that will result in an urban design plan (Mehaffy, 2008). A general trend alongside the increasing complexity of technology and the city since WWII has been a heightening of the importance of the subject in the design process and localist/anti-universalist approach. This thread has run through the work of Jane Jacobs and, more

recently and specifically, Christopher Alexander (Alexander et al, 1987) and Andres Duany (Mehaffy, 2008).

In order to ensure an incremental and more context-appropriate redesign of the urban spaces we inhabit, these theorists and others today argue for an emphasis on process as opposed to product. The discourse in urban design and landscape architecture increasingly focuses on place-making and the importance of responding to contextual elements. This reorganization of priorities in urban design set the stage for the proliferation of a number of movements intended to provide methods for translating local culture and identity into urban design and planning policy. Namely, these movements include the work of the New Urbanists, the development of form-based codes to replace traditional Euclidean zoning, the Community Voice Method (Cumming \& Norwood, 2012), and the proposed generative code of Christopher Alexander (Alexander et al, 1987) (Mehaffy, 2008). 
The New Urbanism movement is based on the work of Andres Duany and Elizabeth Plater-Zyberk as they proposed a return to walkable, community oriented urban spaces. The ten principles of New Urbanism emphasize walkability, connectivity, mixed-use \& diversity, mixed housing, quality architecture \& urban design, traditional neighbourhood structure, increased density, green transportation, sustainability, and quality of life (newurbanism.org, 2016). While New Urbanism rejects the calculating rationalism of modernism for community-based processes for implementing traditional community designs, it is value-laden with a Western bias. New Urbanism may attempt to recreate a local neighbourhoods historic built form, but its recreations are steeped in colonial planning processes that do not reflect the diversity of indigenous design history.

Form-based codes have arisen in recent years as a method of ensure the design of neighbourhood spaces processes as the local community desires. This type of design regulation uses an extended period of public consultation to gain consensus around an urban design master plan for a neighbourhood, then overhaul zoning regimes to put it into practice (Form-based Codes Institute, 2016). Form-based codes as a tool lend themselves to Indigenous urban design processes as they put into regulation the urban design principles that represent the demands of local populations. 
The Community Voice Method (CVM) was pioneered in North Carolina as an iterative process of community consultation and consensus-building in land use planning (Cumming \& Norwood, 2012). The method alternates between periods of engagement and analysis, each time presenting a revised vision to stakeholders that has arisen out of previous iterations. It has the dual intention of creating a more inclusive design methodology and ensuring participants are armed with information provided by research professionals and other stakeholders. The method is designed specifically for use in communities do not have a history of successful planning initiatives, which lends itself well to the situation of growing Indigenous communities in Canadian cities. The CVM is used primarily for decision-making around land use planning and does not involve participants in the detailed design process to the degree that Alexander has proposed or even the New Urbanist approaches.

Christopher Alexander's proposed Generative Code from A New Theory of Urban Design (Alexander et al, 1987) aimed to bring the process of design as close to the spaces being designed and people affected as possible. Mehaffy (2008) summarizes:

"The "generative" design method of A New Theory focused less upon the specification of a final form through schematic planning, and more on the stepwise process by which a form might emerge from the evolutionary actions of a group of collaborators. In so doing, it challenged the notion of "design" as a progressive expression of schematic intentions, and argued for a conception of design as a stepwise, non-linear evolution in response to a series of contextual urban factors." 
These selected rethinkings of the design process provide clues as to what a reconceptualization of urban design practice in Winnipeg may provide urban Indigenous communities.

\section{Decolonization}

'This complex process of 'decolonization' won't be easy, but it must be done, not just to design healthy, sustainable, and equitable cities for the future, but also to address deep historical wounds of injustice and inequity that are most manifested in cities. For instance, the new urban planning must include everyone in the community, particularly the Indigenous communities who have been marginalized and absent from planning and decision-making spaces." (Sami, 2015)

This emphasizes the necessity of making spaces for everyone, with everyone.

The post-modern architecture movement was strongly related to this tenet, as it's context-dependent designs stood in direct opposition to the universalist approach of preceding modernist architecture. Writing on urban design in the 1980's, Roger Trancik (1986) advocated for greater consultation of stakeholders in the neighbourhoods of the city.

\section{Beyond Multiculturalism}

Though it is important to ensure consultation of all affected groups is practiced throughout the planning and design process, there is a distinction that must be made between Indigenous groups and all other stakeholder communities. Porter (2013) emphasizes that Indigenous considerations in planning may not fit into the usual planning process as they challenge the very basis of Western land use planning tradition. By virtue of original occupation, Indigenous groups are entitled 
to accommodation in the political process (Maaka \& Fleras. 2000). For this reason, the discourse on Indigenous urban planning must go beyond current considerations of Canadian multiculturalism.

"Indigenous" is often used in urban design as a word meant "responding to the preexisting local place", in direct opposition to imposing order from the outside. This is how it is used in Trancik (1986). In this way we must ensure that spaces are designed for the people who will use them specifically, and responding to the surrounding context. But we must go beyond considering 'Indigenous' to mean consulting the local community. As Maaka \& Fleras (2000) note, Indigenous in reference to people means preexisting in a location and therefore entitled to specific accommodation. In Canada this philosophy has found form in the federal government's mandated "Duty to Consult". As Canada's Indigenous population maintained a functioning society before colonization by European nations, their situation is different from later immigrants, which gives them greater entitlement to self-government and self-determination (Porter \& Walker. 2005: 331).

\section{Targeting Services and Programs}

While recent progress on practicing a multicultural urban planning process has brought a greater acknowledgement of the pluralism of the Canadian population and measures meant to include a greater segment of society, it appears a onesize-fits-all approach is still prevalent. According to a study by the Federation of Canadian Municipalities, only $4 \%$ of those surveyed were providing services 
specific to Aboriginal communities (Mountjoy. 1995: 319). This demonstrates that while the salient theory supports culturally-relevant service provision in Indigenous communities, municipal government practice is not following suit.

\section{Streams of Analysis}

Recent literature on the relationship between Indigenous peoples and the urban planning process has resoundingly voiced the need for greater inclusion. The means by which a more effective relationship could be forged are less agreedupon by the academic community. Hildebrand (2012) associates the literature with three "streams of analysis": positivist approaches, Indigenous worldviews, and radical critiques. These three streams help to situate proposed alternatives around methods of current practice.

The first stream of analysis, encompassing literature that views planning as a rational and objective process, is also most accepting of the status quo. Works in this stream expound the merits of the western planning process and advocate for its adoption by Indigenous communities (Hildebrand, 2012). Such a perspective appears more concerned with helping design Indigenous communities than with understanding and promoting Indigenous community design.

Trancik's (1986) use of this philosophy fits within Hildebrand's (2012) first stream of positivist urban planning. He advocates for greater consultation by urban designers. "Like designers of houses, we must meet the client when designing cities and learn how to use community participation as a positive factor in the 
creation of urban form" (Trancik, 1986, Pp. 233). This accepts fully the current planning and urban design process, without acknowledging any bias that may arise from the process. While Trancik rejects the imposing of external architectural principles on local urban design projects, he appears to embrace the imposing of an external process with the intent of arriving at internally-derived architectural principles.

This exposes the differing timelines of architectural and planning theory that are partly responsible for the divergence of Hildebrand's (2012) three streams of analysis. As the values of post-modern architecture proliferated in the field of urban design from the 1980's on, the planning field appears to have been slower to jump on board. Where architecture has characteristically focussed on products, urban planning features a deeper obsession with processes. While post-modernism has brought more strongly context-specific built forms, there has been little done to embrace context-specific processes. The following two streams of Hildebrand's (2012) analysis respectively represent attempts to alter and reject the planning process. Where the first stream accepted the Western tradition of urban planning as universally rational and objective, the second (and especially) third stream adopt more Indigenous means to achieve the more Indigenous ends of urban design.

The second stream puts more of the focus on Indigenous worldviews as the basis for the urban planning process (Hildebrand, 2012). Where the previous 
stream follows the rational planning process to include consultation with First Nations groups, this stream reformulates the process along lines that reflect Indigenous epistemology.

The third stream includes critiques from writers who reject the planning process altogether as a Western construct that only reinforces colonial power structures (Hildebrand, 2012). Here, Walker and Belanger (2013) promote the "decentring of Western authority" and its replacement with an Indigenous-led process that recognizes the existence of multiple ways of doing within the same space. Also included is Alton's "Lower Athabasca Regional Counterplan" (2014) which puts forward a radical rethinking of how land-use and resource planning is done with Indigenous communities in Northern Canada.

Within each of these streams runs a common thread of increasing the ability of Indigenous communities to interact with the design of the places they inhabit. In terms of application in the Canadian context, Walker and Belanger (2013. Pp. 201-207) specify recommendations for large prairie cities: “1) relationshipbuilding declaration and accord, 2) protocol agreements on areas of mutual interest, 3) communication and joint governance, 4) urban reserves, services and compatibility agreements, and regional relationships, 5) aboriginal citizen participation and engagement." 


\section{Chapter Four: Precedent Study}

To build on theoretical understanding of Indigenous inclusion in urban design, an exploration of relevant practices was undertaken. Due to the emerging nature of the field, there are very few cases that provide situational lessons for planners in Winnipeg. Any strategies undertaken in Winnipeg will be applying theoretical ideas in ways not commonly seen in the Canadian context. The following cases are examples of Identity being included in urban design to varying degrees.

\section{Establishment of Indigenous Advisory Body}

CFB Rockcliffe in Ottawa is a former military base within the city limits that was declared surplus in 2004 and given to Canada Lands Corp. The Algonquins of Ontario made a claim on the land which stalled the proposed development but led to a multi-million dollar settlement. They were also included in some elements of the redevelopment's design - including a statue on a lookout over the river, as well as street-naming (Pearson, 2015). This represents compensating a FN for dishonoured treaties by including their values in some aspects of a development. This parallels Hildebrand's lowest level of Indigenous planning and consultation, requiring no adjustment of the process or perspectives and only incorporating some homages to Indigenous groups in the ultimate design (Hildebrand, 2013).

The University of Manitoba hosted an international design competition titled Visionary (re)Generation with the aim of developing a new campus plan. An 
criteria for assessing submissions was the inclusion of Indigenous design as an important component. The competition stipulated that "visibility of the region's cultural diversity and Indigenous cultures must be in explored in the design of the built environment" (University of Manitoba, 2016). To better understand what this entailed and how it could be incorporated, a symposium was held to explore similar movements from settler-states around the world. In addition, an elders council was created to begin the process of developing a set of principles for Indigenous design to guide campus development (Bellamy, 2015). This initiative is on a smaller scale than Winnipeg as a whole, but is from a public institution and so the impacts may be far-reaching and may spark further discourse in Winnipeg as a whole.

An example of an urban design plan for an urban reserve is the Musqueam First Nation Comprehensive Sustainable Community Development Plan, in British Columbia. Musqueam First Nation (between Vancouver and Richmond) was one of the four host First Nations of the 2010 Olympics, and to tie into this they created a community development plan that made an attempt to translate their values into physical design. This represents a self-directed FN process of introspection and derivation of values for use in urban design. There is potential for valuable discussion of Indigenous values in planning, but the scale is small and it is not within a larger municipal structure so the impact is less than it would 
be. Musqueam shows the greater ability of a FN community to translate identity into urban design within the bounds of their territory.

\section{Auckland Design Manual, Auckland, Aotearoa New Zealand}

This precedent study will examine the development of the Te Aranga Principles in the Auckland Design Manual in Auckland, Aotearoa New Zealand. This precedent has been chosen for its relevance and applicability in the city of Winnipeg. With a population of 1.3 million people, Auckland is of comparable size to Winnipeg. It has the largest Indigenous population of any region in Aotearoa New Zealand, with 137,000 Maori residents, or about $10 \%$ of the total population (Statistics New Zealand, 2006). It is important to note that the Maori people of Aotearoa New Zealand and Canada's Aboriginal people are not one community under the term "Indigenous" but rather relevant due to the colonial relationships that have affected them. While the histories of diverse Indigenous communities vary, the unifying aspect for this research is the uneven power relationship with the dominant society in both nations.

The Te Aranga Maori Design Principles are a section of the Auckland Design Manual: Maori Design that provides direction on processes for enabling Maori urban design throughout the city. They arose out of the Te Aranga Cultural Landscape Strategy and an attempt to adapt traditional Maori knowledge to the urban context of Aotearoa New Zealand's largest city. While the Te Aranga Cultural Landscape Strategy highlighted process-oriented traditional Maori 
values, the Te Aranga Maori Design Principles translate these into outcomeoriented urban design principles, consistent with the intentions of the Auckland Design Manual. The principles have the intent of highlighting Auckland's unique cultural characteristics, place-making, and making the urban landscape more accessible for Maori citizens (Auckland Design Manual, 2016a). As a priority objective, the ADM states:

"The key objective of the Principles is to enhance the protection, reinstatement, development and articulation of mana whenua cultural landscapes enabling all of us (mana whenua, mataawaka, tauiwi and manuhiri) to connect to and deepen our 'sense of place'." (Auckland Design Manual, 2016a)

The Te Aranga Maori Design Principles are a component of the Auckland Design Manual that is dynamic. Regularly occurring meetings of Maori members are held to discuss certain principles and the development of more specific guidelines to guide development. The principles emphasize the need to adapt them to local environments in all cases, ensuring the values of immediately affected stakeholders are represented in the design process, as well as the overarching Maori design principles (Auckland Design Manual, 2016a). Case studies are conducted to test the applicability and effectiveness of the principles at achieving their goals and to inform updates to the principles.

\section{Origins of the Te Aranga Maori Design Principles}

The Auckland Design Manual (ADM) is a non-statutory guide to best practices in urban design intended to guide development by demonstrating the interpretation of existing planning policy in physical form in Auckland (Auckland Design Manual, 
2016b). The ADM refers to local (Unitary Plan), regional (Regional Policy

Statement Objective 2.2) and federal (Resource Management Act, 1991) urban design related legislation and attempts to provide a clearer understanding of the rules for development (Auckland Design Manual, 2016b).

The Sustainable Development Programme of Action (2003) was landmark policy that highlighted the need for Sustainable Cities as one of its four priorities for sustainable development (New Zealand Office of the Auditor General, 2007. Pp.12 ). This arose out of the World Summit of 2002 in which attendees agreed to create national sustainable development plans. The programme of action covered several topics, including human settlements. It noted that one of the roles of cities was to "support social well-being, quality of life, and cultural identities." It also cites Urban Design as a major priority of sustainable development in Aotearoa New Zealand, with an emphasis on cultural identities in the design of cities (New Zealand Office of the Auditor General, 2007). This eventually led to the development of Urban Design Protocol as a document within the Sustainable Development Programme of Action (New Zealand Ministry for the Environment, 2005), which initiated creation of the Auckland Unitary Plan, Auckland Plan (2012), and ADM.

The Urban Design Protocol is a policy document highlighting desirable urban design characteristics and strategies for municipal decision-makers aiming to create distinctive places, functional, sustainable, and equitable towns and cities. 
It mentions the word Maori a mere four times. This apparent lack of consideration for Maori identities in urban design inspired Maori designers, with the support of the Ministry of the Environment, to congregate to formulate the Te Aranga Maori Cultural Landscape Strategy. The term "cultural landscape" was used to reflect the interconnected Maori worldview, as opposed to the siloed term "urban design" (Auckland Design Manual, 2016a).

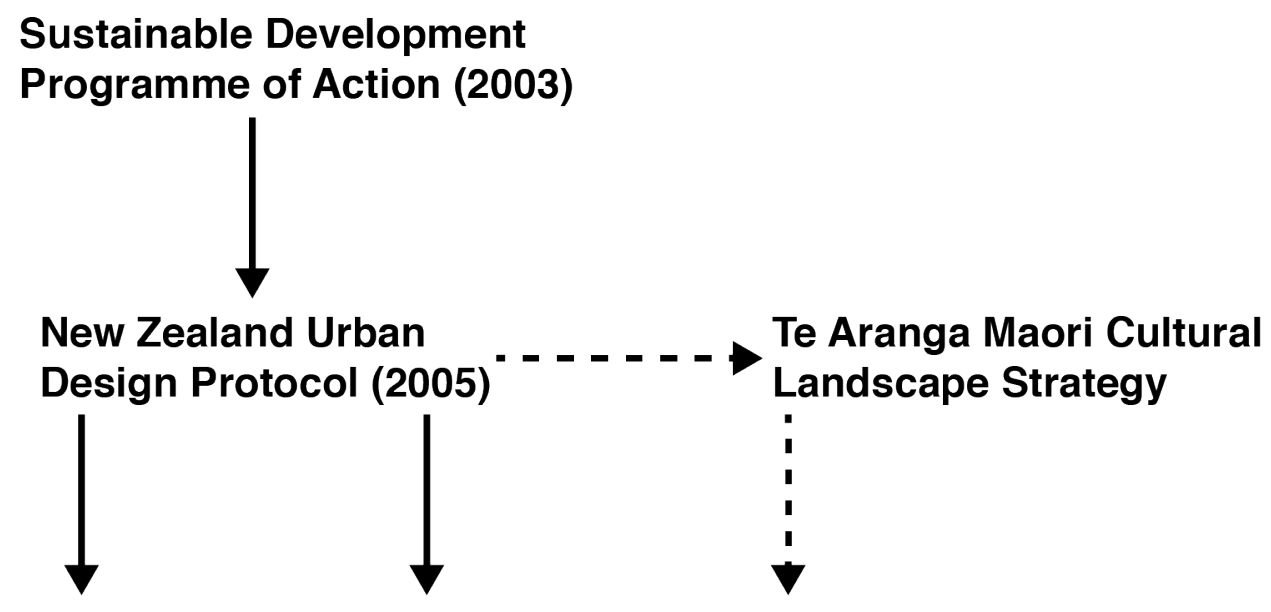

\section{Auckland Plan (2012) Auckland Design Manual}

Figure 2: Policy documents leading to the Auckland Design Manual and Maori Design Principles.

Overall in Aotearoa New Zealand, the impetus for greater inclusion of Maori identities in the design and planning of cities was the rapid urbanization of these populations and the need to ensure cities were able to provide social equity and positive outcomes for citizens from all cultural groups. Designing the city according to the values of Indigenous communities is one of many important strategies with the intention of sustainable urban development. This represents a 
proactive attempt to celebrate unique cultural elements in a territory and manifest this in urban design. The municipal initiation and greater inclusion in the overarching national framework make for a highly impactful initiative.

The originating document for the inclusion of Maori principles in urban design was the New Zealand Urban Design Protocol (2005). This is federal policy, which explains the recognition of national issues that are manifested at the urban scale. Urban planning policy in Canada is mainly found no higher than the provincial level (such as Ontario's Planning Act (1990) and Provincial Policy Statement (2014)) or municipal level (City of Winnipeg Charter (2015). Indigenous issues are under federal jurisdiction in Canada (ss. 91(24) Constitution Act, 1867) and municipalities are "creatures of the province" (ss. 92(8) Constitution Act, 1867). This division of responsibilities may have contributed to a systemic ignorance of Indigenous identities and values in the design and planning of Canadian cities.

The emphasis on Maori cultural landscapes lies at the intersection of Aotearoa New Zealand's Indigenous cultural renaissance and its push for sustainable urban development. The goals of this second movement are varied, but in urban settings they include "the need for cities to be people-oriented, equitable, participative, vibrant, resourceful, biodiverse, energy-efficient, healthy, functional, and regenerative" (Thompson-Fawcett, 2010. Pp. 13). 


\section{Chapter Five: Application in Winnipeg}

The preceding review of literature and best practices will be applied to the situation in Winnipeg, Manitoba, Canada. Winnipeg is an important centre of Canada's Indigenous population as well as notable in the nation's histories of architecture and multiculturalism.

Winnipeg is a former frontier city on the Canadian prairies that today has around 750,000 people in the census metropolitan area (Statistics Canada, 2016). It has both the largest First Nations and Métis populations of any city in the Canada, per capita and in real numbers (Statistics Canada, 2013). Sitting at the confluence of the Red and Assiniboine Rivers, the site of modern day Winnipeg has for many thousands of years been an important site for the Indigenous people of central North America, both for trade and ceremonial purposes.

While the Indigenous population of Winnipeg has been steadily growing since the 1960 's, urban planning processes in the city for many years did not consider at all the cultural implications of their actions. The Plan Winnipeg documents dating from this period focus primarily on physical changes in the city, highlighting priorities of "urban development, housing, transportation, parks and recreation, water supply and distribution, pollution control, and land drainage" (Hildebrand, 2012. Pp. 85-87).

The spaces within Winnipeg have almost exclusively been designed through the lens of European colonialism, despite the rich diversity of populations that inhabit 
them. The oldest and fastest-growing of these non-European populations is Winnipeg's Indigenous population. Prior to the 1970's there was little recognition of the conditions the Indigenous population lived in in inner-city neighbourhoods, and thus fewer attempts to address issues (Hildebrand, 2012. Pp. 86).

\section{Neeginan}

Beginning in 1975, there were some action towards understanding the urban planning implications of the rapidly growing Indigenous population in the inner city. Indigenous residents were much more likely to be living below the poverty line and in neighbourhoods considered to be less desirable than the rest of the city. The discourse had been predominantly about "blighted" neighbourhoods and efforts to stem their growth or clear them entirely (Hildebrand, 2012. Pp. 86). In 1975, a report titled Neeginan: A Report on the Feasibility Study Prepared for Neeginan (Manitoba) Incorporated was published which examined the distribution and experience of Winnipeg's Indigenous population, and studied the feasibility of a proposed "ethnic village" (Damas and Smith Limited.

1975). Indigenous community organizers began the process of developing a cluster of Indigenous-oriented community services in the area of Higgins Avenue and Main Street in downtown Winnipeg. Today, Neeginan is the epicentre of Winnipeg's Indigenous community and features a large number of resources aimed at building community and improving outcomes for urban Indigenous populations (Hildebrand, 2012. Pp. 63). Neeginan is a logical starting place for 
planners in Winnipeg intending to expand engagement with Indigenous communities.

\section{University of Manitoba Campus Plan}

Whereas the Neeginan concept clusters social services targeted at Indigenous people into a focus area, it lacks a discourse about the design of the "ethnic village" it aims to support. The contemporary discourse on Indigenous urban design in Winnipeg has been advanced by the University of Manitoba in its Visionary/Regeneration campus planning symposium "Coming to a Common Place" explored previously in this paper. Any examination of Indigenous design in Winnipeg as a whole will learn from the outcomes of this process. This includes the contributions of the Indigenous advisory council as the University of Manitoba attempts to develop an urban neighbourhood according to Indigenous design principles (University of Manitoba, 2016).

\section{Urban Partnerships}

The Canadian government has recognized the increasing need to include Indigenous peoples in urban development, and so has created an Urban Aboriginal Strategy. The Urban Aboriginal Strategy is multi-pronged, with dual focus on Community Capacity Support and Urban Partnerships. Community Capacity Support is a program that provides "operational support to urban Aboriginal organizations" while Urban Partnerships is a program that "encourages partnerships and community planning" (Indigenous and Northern 
Affairs Canada, 2014). Urban Partnerships is most relevant to the purposes of this paper, as it draws Indigenous perspectives into Canada's institutions instead of pushing resources to Aboriginal non-governmental organizations. Urban Partnerships provides funding from the Canadian government to municipalities, health and educational institutions, and Aboriginal not-for-profit organizations with the goal of supporting Aboriginal people's participation in the Canadian economy.

Portage Place, the largest shopping mall in downtown Winnipeg, recently announced that it was contracting out security services to an Indigenous-led company that prioritizes the inclusion and promotion of Indigenous culture and values (Brohman. 2016). This is an important step in creating space that responds to the needs of Winnipeg's Indigenous people. The policing of spaces according to settler traditions has historically ensured that these spaces responded only to settler population values. Deeper than the policing of spaces, however, is the way that these spaces are designed in the first place. To understand the biases inherent to designing the urban landscape in Winnipeg we will examine the process that guides urban design in the city.

\section{Urban Design in Winnipeg}

Urban design in Winnipeg is guided by the following documents:

- Our Winnipeg (2011)

- Complete Communities Direction Strategy (2011)

- Downtown Winnipeg Urban Design Guidelines (2005) 
Each of these documents will be examined for inclusion of indigenous communities in the urban design process. A keyword search is undertaken to compare the number of mentions across documents and gain an understanding of the prevalence of Indigenous urban design inclusion in City of Winnipeg urban design and planning documents.

\section{OurWinnipeg}

Our Winnipeg is the official plan for the City of Winnipeg, and was adopted in 2011 (City of Winnipeg, 2011b). It sets out the vision and goals of the City in terms of functionality, sustainability, and quality of life for residents. It makes some reference to the historic and growing Aboriginal population in Winnipeg, citing specifically the 20,000 person growth between 1996 and 2006. In reference to increased immigration as well as the growing Aboriginal population it states: "Diversity will continue to challenge Winnipeggers to be inclusive and responsive to difference and will provide our city the opportunity to be a magnet

for talented, creative new residents in an increasingly interconnected world." (City of Winnipeg, 2011b, Pp. 13). 


\section{OurWinnipeg}

Term

Number of Mentions

Aboriginal 43

First Nations

Indigenous

Métis

Multicultural

Figure 3: Frequency of key words relating to Indigenous people in OurWinnipeg (City of Winnipeg, 2011b).

In Chapter 3: Quality of Life, Direction 5 of section 3-1 (Opportunity) the document states: "Acknowledge that Aboriginal Winnipeggers bring a diverse richness of cultures, traditions, languages, teachings, values, skills and perspectives to our city."

Accompanied by the enabling strategies:

- Collaborate with Aboriginal communities to enhance current practices and policies to respect cultural differences.

- Collaborate with Aboriginal Winnipeggers to ensure that all Aboriginal residents have opportunities to live, work and play in our city.

- Work with community partners to raise the profile of Aboriginal culture in our community.

In the same chapter, Direction 9 stipulates that the City should collaborate with developers to ensure privately developed spaces are accessible for people of all 
abilities and are designed to be age-friendly. There is no mention of the design of spaces to reflect the varied interests of multiple cultural groups or Indigenous identity.

\section{Complete Communities}

The Complete Communities Direction Strategy (2011) is a more detailed document that exists under OurWinnipeg (2011) and is the land use and development plan for the entire city (City of Winnipeg, 2011a).

\section{Complete Communities}

Term

Number of Mentions

Aboriginal

First Nations

Indigenous

Métis

Multicultural

Figure 4: Frequency of key words relating to Indigenous people in Winnipeg's Complete Communities Direction Strategy (City of Winnipeg, 2011a).

Chapter 10: Aboriginal Economic Development Zones, Direction 1 of Complete

Communities states that the City will work with Treaty Land Entitlement First

Nations to negotiate Municipal Development and Service Agreements. This encourages an openness to the establishment of urban First Nations reserves 
within the city limits, but does not make mention of such respect for Indigenous rights to space within the city of Winnipeg, off-reserve.

Chapter 12: Urban Design stipulates that the City develop and urban design strategy that ensures Winnipeg is aesthetically pleasing, capitalizes on its unique physical characteristics, and responsive to its many communities. Direction 2 of this chapter specifies: "For new development projects, the City and development community should seek community involvement and endeavour to express the values, needs and aspirations of the people for whom the place is being designed." This commits the City to take action on expanded consultation and attempts to create culturally-determined physical spaces.

\section{Downtown Winnipeg Urban Design Guidelines}

The Downtown Winnipeg Urban Design Guidelines are the most prescriptive urban design document in use. The guidelines specify a five-step process:

1. Early consultation

2. Application

3. Design review

a. City Staff

b. Urban Design Advisory Committee

4. Recommendation

5. Permit

(City of Winnipeg: Planning \& Property Development, 2015) 


\section{Downtown Winnipeg Urban Design Guidelines}

Term Number of Mentions

Aboriginal 0

$\begin{array}{ll}\text { First Nations } & 0\end{array}$

Indigenous $\quad 0$

Métis 0

\begin{tabular}{l|l} 
Multicultural & 0
\end{tabular}

Figure 5: Frequency of key words relating to Indigenous people in the Downtown Winnipeg Urban Design Guidelines (City of Winnipeg: Planning \& Property Development, 2015).

The Downtown Winnipeg Urban Design Guidelines state:

"All projects built in the downtown should recognize and celebrate the following principles:

- Enhance pedestrian comfort, safety and accessibility

- Create identifiable places where appropriate to the context of the urban fabric

- Respect the urban tradition of streets and blocks

- Celebrate and build on the best features of the surrounding context

- Contribute to important vistas and linkages

- Animate the interface between interior and exterior space"

(City of Winnipeg: Planning \& Property Development, 2015)

These principles appear culturally-neutral, or culturally-uninformed - which

ensures a default promotion of majority Western design ideals, the status quo.

Policy "Respect the urban tradition of streets and blocks" especially promotes a

Western tradition and potentially discourages alternative urban design ideals.

The Urban Design Guidelines dictate desired urban forms for the downtown area 
but fail to promote the integration of multiple cultural perspectives, specifically those of Indigenous groups.

Through an analysis of these policy documents that guide planning and urban design decision-making in Winnipeg, it becomes clear that an acknowledgement of the cultural promotion inherent in all design and land-use decision-making processes is lacking. Though some policies in OurWinnipeg support the inclusion of cultural identities in planning and design processes, recommendations such as the creation of a city-wide urban design strategy have yet to be followed. It is especially clear through the keyword-search that Indigenous engagement is included to some degree in urban planning processes, but is almost non-existent in urban design policy. Despite an understanding of the important and growing role that Indigenous communities play in Winnipeg, and of the need to consider these issues separately from the wider discourse on multicultural planning, the City has not taken steps to put these ideas into action. 


\section{Chapter Six: Recommendations}

The need to enable Indigenous urban planning in Winnipeg may be more pressing than in other cities, but it is not alone. Few large cities in Canada and other British settler-states have Indigenous populations of comparable scale to Winnipeg's, and even fewer have formalized processes for including Indigenous identities in the design of their urban landscapes. However, there are a number of smaller examples that planners in Winnipeg can learn from, and a relevant precedent in Auckland which provides a number of practical lessons. Beyond practice, there is a rich body of theory built up over many years that planners can look to an apply in Winnipeg. The emerging nature of this topic means that any action Winnipeg takes to reconfigure its planning and design processes for greater application of Indigenous values will be studied and replicated elsewhere. In evaluating the existing body of precedents and theory, there are a number of actions for the City to consider.

Building from the review of Indigenous urban planning and design theory, the study of precedents, and the examination of the Winnipeg planning and design context, a series of recommendations for the City of Winnipeg have been developed. These recommendations are oriented to the municipal order of governance, but it is clear that Indigenous urban design is a multi-jurisdictional issue that includes both the federal and provincial governments as well. 


\section{Practice Multicultural Planning}

Indigenous communities possess rights and a historical context that differentiates them from other ethnic enclaves in Canadian cities, but many of the processes the urban planning profession in Canada has adopted over the past two decades to entrench official multiculturalism meet the base needs of engagement with urban Indigenous populations. Qadeer (1997) recognizes the necessary ability of the planning profession to recognize ethnic and cultural identity as requisite analytical approaches. In Winnipeg's neighbourhoods with concentrations of Indigenous members, it is evidently important to understand the specific needs and characteristics of these communities.

The provision of services in Manitoba is already culturally-determined in certain instances. For example, the Child and Family Services (CFS) system provides a relevant precedent. Children brought into the care of Manitoba CFS are given access to services that are divided under four authorities: First Nations of Southern Manitoba CFS Authority, First Nations of Northern Manitoba CFS Authority, Métis CFS Authority, and General CFS Authority, at the discretion of the parents, the self-identification of the children, and of the authorities themselves (Government of Manitoba, 2016a) (Government of Manitoba, 2016b). The division of services arose in the 1990's out of a demonstrated need for culturally-relevant services due to inequalities among children in care in the province. The authoritative division of service provision attempts to mitigate the 
colonial cultural imposition of a singular system and provides culturallyappropriate services (Hudson and Mckenzie, 2003). The system suffers from the same inter-governmental jurisdictional issues as an Indigenous urban design process, as the provincial entity was created without federal government involvement despite their being the main funder of social agencies for First Nations (Hudson and Mckenzie, 2003. Pp. 57). There has also been noted a funding deficiency for First Nations services off-reserve compared to on-reserve services (Hudson and Mckenzie, 2003. Pp. 51). This aligns with the persistent notion that First Nations rights to accommodation exists only on reserve land, in family services or urban design (Peters, 1996).

Another implication of the multicultural era of urban planning is how the products of public consultation are analyzed. With particular attention paid to minority communities, it is essential that the lessons that arise from engagement efforts are addressed in a method appropriate to that community (Qadeer, 1997. Pp. 485). Trancik (1986) endorsed sensitive and innovative methods of consultation and analysis, and Qadeer included specific attention to minority communities. In Winnipeg, it is imperative that Indigenous communities are not just the subjects of consultation but also involved in the interpretation and implementation of findings. An increasingly common practice in Indigenous design processes is the creation of a body of Indigenous leaders and designers to inform processes, interpretation, and implementation. This can be seen in the Indigenous design panels for the University of Manitoba Visionary/Regeneration Competition 
(Bellamy, 2015) (University of Manitoba, 2016) and CFB Rockcliffe redevelopment (Pearson, 2015).

To greater fulfill the necessities of multiculturalism in the planning process, planners must innovate new approaches for broader and deeper citizen involvement in processes (Qadeer, 1997. Pp. 485). The City of Winnipeg must embrace a people-oriented approach that is culturally responsive, beyond the typical neighbourhood or ward level orientation of engagement processes (Walker and Belanger, 2013. Pp. 207). The city must understand the centres and organizations that are the strongest anchors in Indigenous communities of the city and leverage their networks for greater engagement of Indigenous citizens. Community anchors may be cross-jurisdictional and thus have the potential to be more effective at targeting specific cultural groups.

Beyond diverse citizen involvement in planning processes, decision-making bodies must be culturally representative of the communities they preside over. Qadeer (1997, Pp. 485) saw this as an important next step in multicultural planning that had not yet occurred in Canadian municipalities. Low representation in decision-making bodies was determined to be a contributing factor to the inadequate level of Maori cultural principle adoption in local governments in Aotearoa New Zealand (Awatere et al, 2013. Pp. 242). While the continuing growth in population of Winnipeg's Indigenous population compared to other groups may lead to greater representation in democratic bodies such as the 
municipal government, the City of Winnipeg should take measures to ensure members of relevant Indigenous communities are employed in the planning department in a capacity that increases cultural understanding and representation.

\section{Embrace Indigenous Neighbourhoods as Integral}

A primary stepping stone in including Indigenous identities in the design of the city is to view the communities of Indigenous people as integral pieces of the urban fabric. There is a lingering tendency on the part of citizens and also the institutions that represent them to consider Indigenous populations as transient and unrooted. The image of the indigenous Canadian is often stylized as being closer to nature, and therefore incompatible with life in the city. More specifically, many see the reserve as being the true home for Indigenous people and therefore any communities in urban areas off-reserve are seen as temporary or even unwelcome (Porter, 2013) (Peters, 1996). This conceptualization is incongruent with the reality that the majority of Canada's Indigenous population lives in cities (Statistics Canada, 2013). The concentration of this population in urban areas has been growing for several decades, a trend mirroring the general Canadian population.

It is important that planners approach Indigenous communities in cities as stable, long-term communities. This treatment is much the same as for any other neighbourhood of the city, though the methods of consultation may be different. 
As previous study has shown, the conceptualization of the city as "home" is found in the vast majority of Indigenous urban residents (Environics Institute, 2011), which may make for communities with a high potential for engagement in the processes of the City.

\section{Recognize Coexisting Value Systems}

An integral part of the process of decolonization is the cessation of value imposition by one group upon another. As planners in Winnipeg move to greater reflect the values and culture of the Indigenous population in the process of planning and design, they must understand where European colonial values are present (Walker \& Belanger, 2013. Pp.196). With this knowledge of values that are inevitably present in all processes, planners can act to ensure they do not override those of consulted populations.

While theorists in Hildebrand's (2012) critical third stream of analysis question the very basis of all western planning tradition in engagement with Indigenous groups, a more practical approach for planners in Winnipeg is the establishment of specific zones where Indigenous communities are the main proprietors and identity holders. In practice this is the process of establishment of urban First Nations Reserves in Winnipeg, which simplify the processes of identifying stakeholder communities, and recognizing Indigenous title in urban areas. The City of Winnipeg should develop a strategy to encourage urban reserve / 
Aboriginal economic development zone creation in a streamlined fashion and in appropriate locations.

The City of Winnipeg must proactively work with interested First Nations communities to encourage urban reserve development within the municipal boundaries. While the settlement of land claims is a federal responsibility, the City of Winnipeg can enact policy that streamlines the process of signing a municipal servicing agreement and reduces the time needed for negotiation between the City and First Nation. Urban reserves offer an important opportunity for greater Indigenous autonomy in urban communities.

The strategy should also aim to bring the greatest economic benefit to both proprietors of urban reserves and the rest of Winnipeg, while providing greater engagement and opportunities for self-expression of Indigenous communities throughout the city. The City should be prepared for servicing agreements between the urban reserve and Winnipeg, and recognize the Indigenous community's right to adhere to their own value system for planning and urban design processes on-reserve (Walker and Belanger, 2013). Though compatibility between land-use plans is desirable, it is not the prerogative of the City to enforce a Western planning tradition on the reserve lands of the Indigenous community. 


\section{Kapyong Barracks}

Specifically, the findings of this paper suggest the City of Winnipeg should support and plan for the establishment of an urban reserve at Kapyong Barracks. Due to advantages of geography, clearly-defined stakeholders, and autonomy as previously explored, the Kapyong urban reserve would allow for the expression of Indigenous cultures in the design of built environments.

While the design discourse thus far has centred around fitting such an entity into the existing neighbourhood "seamlessly" (Welch, 2015), there is a strong case to suggest that the opportunity to develop Indigenous urban design should not be missed. Indigenous leaders have assured the public that development within the urban reserve would be indistinguishable from lands in the rest of the city, partly out of a reaction against negative and inaccurate public preconceptions of what a reserve looks like. While respect for surrounding land uses is important, the creation of a space that enables Indigenous expression may be more so. Attempting to make the reserve land indistinguishable from the rest of the city implies a continuation of the western tradition of urban design and thus a missed opportunity provide spaces for all residents of the city.

\section{Beyond the Reserve}

One of the starkest differences between the urban design process in Winnipeg and of the case in Auckland is that Auckland's Maori Urban Design Principles were not initiated by some desire within the city alone to better engage 
Indigenous communities in city-building. Auckland's were a part of the national urban design protocol, which had highlighted the need to reflect Maori identities in the design of spaces. Andersen (2013) affirms that municipalities must act on Indigenous planning, without waiting for higher levels of government to take the lead - but it is this jurisdictional difference that has contributed to the disconnect. Where New Zealand's federal level of government concerns itself with urban design as well as with Indigenous issues, an opportunity is created to use one to address the other. Canada does not have this overlap to the same degree and thus cities must find their own imperatives for addressing the issue. A few of them have been noted in this paper, with the most important being the sheer size of the Indigenous population explosion cities have witnessed in recent decades and a need to ensure new residents have the sense of belonging that leads to strong communities.

In traditional off-reserve urban communities of Indigenous people, the City must aim to ground as much of the engagement process in the local community as possible. While this is true for all neighbourhoods of the city and especially through the lens of Canadian multiculturalism, Indigenous rights go beyond multiculturalism and thus groups are entitled to greater downloaded responsibilities from the municipal government (Porter, 2013, Pp. 303). Rather than incorporating Indigenous perspectives, it must be the goal of planners in 
Winnipeg to respect equally the dual value structures of Indigenous groups and the Western tradition.

Such equal recognition of coexisting value systems will require a strong framework for communication between stakeholder parties and a commitment to joint governance in areas of mutual interest (Walker and Belanger, 2013. Pp. 204). This framework may involve a mandated schedule of meetings between municipal and Indigenous decision-makers, and a match-making of councillors and city staff with relevant members of the Indigenous community structure.

"Can we bring ourselves to a point of meaningful recognition of Indigenous coexistence in cities? If we are to do so, cities must be seen as unsettled places where Indigenous title, connection, and contemporary culture rightfully belong." (Porter, 2013. Pp. 304)

\section{Create Stakeholder Discussion Space}

The City of Winnipeg must enact policy to strengthen relationships between the municipality and Indigenous communities, and create a discussion space between these communities, private developers, and other stakeholders. The creation of such a space in Aotearoa New Zealand increased Maori participation in the development process and enabled local Maori communities to work with private developers with the aim of respecting Maori design principles (Awatere et al, 2013. Pp. 255). Relationship-building initiatives currently underway in Canada include the federal government's Urban Partnerships program as part of the Urban Aboriginal Strategy (Indigenous and Northern Affairs Canada, 2014). At 
the municipal scale an effective platform may build off the previously mentioned match-making of municipal and Indigenous leaders to add private interests in a repeated and mutually beneficial discussion of interests.

A common thread through much of the literature and precedent study is the need to focus efforts for Indigenous urban design on processes as opposed to the products. While this research paper initially arose out of an attempt to write a form-based code to guide future develop of an urban reserve at Kapyong Barracks, a review of literature emphasized the importance of context-specific designs grounded in the genius loci and local cultures. While Indigenous design principles have been derived for projects around the world through various processes, it is understood that such products must not be seen as answers to the question of Indigenous design.

Rather, the processes of derivation of these products are the answers that may be learned from. In short, the goal is functional Indigenous urban design over substantive Indigenous urban design in that the means are of more importance than the ends. For this, the City of Winnipeg may look to the emerging and established design and consultation processes reviewed (Trancik, 1986) (Cumming \& Norwood, 2012) (Mehaffy, 2008) (Alexander et al, 1987). The Indigenous consultation process itself that the City adopts must be rooted in an understanding and respect for Indigenous culture (Hildebrand, 2012), led by members of the respective communities. 
The City of Winnipeg must develop an overall Indigenous urban design strategy that pieces together each of the recommendations here into a cohesive plan of action for institutionalizing a process and series of interventions aimed at enabling Indigenous urban design in the city. The relevant experience of Auckland, ANZ offers a model and demonstration of the potential effectiveness of such a policy approach (Auckland Design Manual, 2016a) (Wannsborough and Mageean, 2000. Pp. 189). 


\section{Chapter Seven: Conclusion}

This is a classic multi-jurisdictional planning issue that suffers from a vague definition of roles for the affected parties and a siloed public service that may struggle to address issues of a certain scope. While federal governments address Indigenous issues in Canada, urban design is practiced at the municipal scale. Furthermore, municipalities are creatures of the province and thus not affiliated with the federal government as directly. As this paper has emphasized, Winnipeg must attend to the culturally relevant design of urban spaces for its own motivations without relying on direction from the federal government.

As Winnipeg's Indigenous population continues to grow and transform the culture of the city, it becomes increasingly important that the neighbourhoods these communities inhabit reinforce a shared set of cultural characteristics. It has been shown that planning departments around the colonized world are not enabling Indigenous urban design enough. A large body of theory supports a number of initiatives aimed at reducing the colonial influence of the design of Indigenous spaces, but few jurisdictions have put this into practice. While some such developments are occurring in Aotearoa New Zealand, Winnipeg has the opportunity as Canada's urban Indigenous capital to chart a new course in urban design practice. Drawing on the existing body of knowledge, planners in Winnipeg must alter current practices so as to ensure the design of urban spaces reflects the identities of the Indigenous communities that inhabit them. 


\section{References}

Adams, M. \& Gosnell-Myers, G. (2013). Don't forget Canada's urban Aboriginals. They're not just passing through. The Globe \& Mail. Updated: 22 January 2013. Accessed: 10 December 2015. Retrieved from: http://www.theglobeandmail.com/opinion/dont-forget-canadas-urbanaboriginals-theyre-not-just-passing-through/article7599448/\%5d/

Alexander, C., Neis, H., Anninou, A. and King, I. (1987). A New Theory of Urban Design.New York, NY: Oxford University Press.

Alton, C. (2014). The Lower Athabasca Regional Counterplan (unpublished Masters thesis). Harvard University, Cambridge.

Anderson, C. (2013). Urban Aboriginal Planning: Towards a Transformative Statistical Praxis. In R. Walker, T. Jojola, \& D. Natcher (Eds.), Reclaiming Indigenous Planning. (pp. 260-282). Montreal \& Kingston: McGill-Queen's University Press.

Auckland Design Manual. (2016)a. Guidance for Te Aranga Principles Accessed: 8 February 2016. Retrieved from: http://www.aucklanddesignmanual.co.nz/design-thinking/ maori-design/te_aranga_principles

Auckland Design Manual. (2016)b. What is the Auckland Design Manual? Accessed: 18 January 2016. Retrieved from: http://www.aucklanddesignmanual.co.nz/ about-the-adm\#/about-the-adm/what-is-adm

Awatere, S., Rolleston, S., and Pauling, C. (2010). Developing Maori Urban Design Principles. In K. Stuart \& M. Thompson-Fawcett (Eds.), Tãone tupu ora: Indigenous knowledge and sustainable urban design. (pp. 17-23). Wellington, New Zealand: Steele Roberts Aotearoa.

Awatere, S., Harmsworth, G., Rolleston, S., and Pauling, C. (2013). Katiakitanga o Nga Ngahere Pohatu - Kaitiakitanga of Urban Settlements. In R. Walker, T. Jojola, \& D. Natcher (Eds.), Reclaiming Indigenous Planning. (Pp. 236259). Montreal \& Kingston: McGill-Queen's University Press.

Bellamy, B. (2015) Racial Peace Through Architecture. Winnipeg Free Press. Updated: February 9, 2015. Accessed: 16 February 2016. Retrieved from: http://www.winnipegfreepress.com/business/racial-peace-througharchitecture-291233931.html 
Brohman, E. (2016). "Portage Place honours Joseph Meconse 1 month after he was kicked out of mall". CBC News. Update: 11 March 2016. Accessed: 15 March 2016. Retrieved from:

http://www.cbc.ca/news/canada/manitoba/winnipeg-portage-placehonours-indigenous-elder-joseph-meconse-1.3486564

City of Winnipeg. (2011)a. Complete Communities Direction Strategy. Retrieved from:

http://www.winnipeg.ca/interhom/CityHall/OurWinnipeg/pdf/CompleteCom munities.pdf

City of Winnipeg. (2011)b. OurWinnipeg. Retrieved from: http://www.winnipeg.ca/interhom/CityHall/OurWinnipeg/pdf/OurWinnipeg.p df

City of Winnipeg. (2015). Accessibility Design Standard: Third Edition. Retrieved from:

http://winnipeg.ca/ppd/Universal_Design/PDF/Access_Design_Standards. pdf

City of Winnipeg: Planning \& Property Development. (2005). Downtown Urban Design Guidelines. Retrieved from:

http://winnipeg.ca/ppd/planning/pdf_folder/DntwnDesignGuidelines.pdf

City of Winnipeg: Planning \& Property Development. (2015). Downtown Urban Design Review. Updated: 4 November 2015. Retrieved from http://winnipeg.ca/ppd/planning_downtown_urban_design.stm

Cumming, G., Norwood, C. (2012). The Community Voice Method: Using participatory research and filmmaking to foster dialog about changing landscapes. Landscape and Urban Planning 105(4): 434-444.

Damas and Smith Limited. (1975). Neeginan: A feasibility report prepared for NEEGINAN (Manitoba) Incorporated. Winnipeg: Neeginan (Manitoba) Incorporated. Retrieved from: http://imfcentre.net/wpcontent/uploads/2016/01/Neeginan-Feasibility-Report-1.pdf

Dorries, H. (2012). Rejecting the "False Choice": Foregrounding Indigenous Sovereignty in Planning Theory and Practice (Unpublished doctoral thesis). University of Toronto, Toronto. 
Environics Institute. (2011). Urban Aboriginal Peoples Study: Winnipeg Report. Retrieved from: http://www.uaps.ca/wp-content/uploads/2010/02/UAPSWinnipeg-report_FINAL.pdf

Form-based Codes Institute. (2016). Form-based Codes Defined. Accessed: 16 March 2016. Retrieved from: http://formbasedcodes.org/definition/

Healey, D. (2005). Attention deficit/hyperactivity disorder and creativity: An investigation into their relationship (Unpublished doctoral thesis). University of Canterbury, Christchurch, New Zealand.

Hildebrand, Jonathan. (2012). University of Manitoba. 'Our Place, Our Home': Indigenous Planning, Urban Space, and Decolonization in Winnipeg, Manitoba. Retrieved from: http://mspace.lib.umanitoba.ca/xmlui/bitstream/handle/1993/8478/hildebra nd_jonathan.pdf?sequence $=1$ \&isAllowed $=y$

Indigenous and Northern Affairs Canada. (2014). Urban Aboriginal Peoples. Accessed: 17 December 2015. Retrieved from: https://www.aadncaandc.gc.ca/eng/1100100014265/1369225120949

Maaka, R., and A. Fleras. 2000. Engaging with Indigeneity: Tino Rangatiratanga in Aotearoa. In D. Ivison, P. Patton, \& W. Sanders (Eds.), Political theory and the Rights of Indigenous Peoples. Cambridge: Cambridge University Press.

Mehaffy, M. W. (2008) Generative methods in urban design: a progress assessment, Journal of Urbanism: International Research on Placemaking and Urban Sustainability, 1:1, 57-75, DOI: 10.1080/17549170801903678.

Mountjoy, T. (1995) Regina perspectives on Aboriginal self-government. In: Peters, E.J. (Ed.), Aboriginal Self-Government in Urban Areas. Institute of Intergovernmental Relations, Queen's University, Kingston, Ont., pp 143150.

Newurbanism.org, (2016), Principles of New Urbanism, Accessed: 17 March 2016, Retrieved from:

http://www.newurbanism.org/newurbanism/principles.html 
New Zealand Ministry for the Environment. (2005). New Zealand Urban Design Protocol. Accessed: 12 February 2016. Retrieved from: http://www.mfe.govt.nz/sites/default/files/urban-design-protocol-colour.pdf

New Zealand Office of the Auditor General. (2007). Sustainable Development: Implementing the Programme of Action. Retrieved from: http://www.environmental-auditing.org/Portals/O/AuditFiles/NZ-sustainabledevelopment.pdf

Ontario Ministry of Municipal Affairs and Housing. (1990). Ontario Planning Act. Retrieved from Government of Ontario website: www.ontario.ca/laws/statute/90p13

Pearson, M. (2015). Former CFB Rockcliffe Development Proposed. Ottawa Citizen. Last updated: 17 September 2015. Accessed: 12 December 2015. Retrieved from: http://ottawacitizen.com/news/local-news/former-cfbrockcliffe-redevelopment-proposed

Peters, E. (1996). Urban and Aboriginal: An Impossible Contradiction? In J. Caulfield \& L. Peake (Eds.), City Lives and City Forms: Critical Research and Canadian Urbanism. (pp. 47-62). Toronto: University of Toronto Press.

Peters, E. J. (2011). Urban Aboriginal Policy Making in Canadian Municipalities. Montreal: Mcgill University Press.

Peters, E. and Walker, R. (2005). Indigeneity and Marginalization: Planning for and with Urban Aboriginal Communities in Canada. Progress in Planning, Volume 63(4). 327-404.

Porter, L. (2013). Coexistence in Cities: The Challenge of Indigenous Urban Planning in the Twenty-First Century. In R. Walker, T. Jojola, \& D. Natcher (Eds.), Reclaiming Indigenous Planning. (pp. 283-310). Montreal \& Kingston: McGill-Queen's University Press.

Qadeer, M. (1997) Pluralistic planning for multicultural Cities: the Canadian practice. Journal of the American Planning Association 63, 481-494.

Rolleston, S. and Awatere, S. (2009). Ngā hua papakāinga: Habitation design principles. MAI Review 2(2). Retrieved from: http://www.review.mai.ac.nz/index.php/MR/article/viewFile/241/241 
Sami, M. (2015). Create healthy cities, decolonize urban planning. Rappler. Updated: 5 October 2015. Accessed: 12 March 2016. Retrieved from: http://www.rappler.com/views/imho/108169-create-healthy-citiesdecolonize-urban-planning

Statistics Canada. 2013. Aboriginal Peoples in Canada: First Nations People, Métis and Inuit. Statistics Canada Catalogue no. 99-011-X. Ottawa, Ontario. Analytical Products, 2011 Census. Last updated 15 December 2013. Accessed: 14 January 2016. Retrieved from: https://www12.statcan.gc.ca/nhs-enm/2011/as-sa/99-011-x/99-011x2011001-eng.cfm

Statistics Canada. 2016. Population of Census Metropolitan Areas. Ottawa, Ontario. Summary Tables, 2011 Census. Last updated: 10 February 2016. Accessed: 14 January 2016. Retrieved from: http://www.statcan.gc.ca/tables-tableaux/sum-som/l01/cst01/demo05 a-eng.htm

Statistics New Zealand. (2006). QuickStats About Auckland Region. Quickstats: 2006 Census. Accessed: 18 January, 2016. Retrieved from: http://www.stats.govt.nz/Census/2006CensusHomePage/QuickStats/Abou tAPlace/SnapShot.aspx?id=1000002

Te Aranga. (2008). Te Aranga Maori Cultural Landscape Strategy. Retrieved from:

http://www.tearanga.maori.nz/cms/resources/TeArangaStrategy28Apr08_I r.pdf

Thompson-Fawcett, M. (2010). Keeping the past in sight to signal ways forward. In K. Stuart \& M. Thompson-Fawcett (Eds.), Tāone tupu ora: Indigenous knowledge and sustainable urban design. (pp. 11-15). Wellington, New Zealand: Steele Roberts Aotearoa.

Trancik, R. (1986). Finding Lost Space: Theories of Urban Design. New York: John Wiley \& Sons Inc.

University of Manitoba. (2016). Coming to a Common Place. Retrieved from: http://umanitoba.ca/faculties/architecture/comingtoacommonplace.html 
Walker, R., Belanger, Y.. (2013). Aboriginality and Planning in Canada's Large Prairie Cities. In R. Walker, T. Jojola, \& D. Natcher (Eds.), Reclaiming Indigenous Planning. (pp. 283-310). Montreal \& Kingston: McGill-Queen's University Press.

Walker, R., Jojola, T., Natcher, D. Reclaiming Indigenous Planning. McGill Queen's University Press. Montreal (2013).

Wannsborough, M. \& Mageean, A. (2000). The Role of Urban Design in Cultural Regeneration. Journal of Urban Design, 5(2), 181-197. 